\title{
Ticks infesting animals in the Sudan and southern Sudan: Past and current status
}

\author{
Authors: \\ Ahmed ElGhali ${ }^{1}$ \\ Shawgi M. Hassan² \\ Affiliations: \\ ${ }^{1}$ Veterinary Research \\ Institute, Khartoum, Sudan \\ ${ }^{2}$ Department of Parasitology, \\ University of Khartoum, \\ Sudan \\ Correspondence to: \\ Ahmed EIGhali \\ Email: \\ elghaliaahmed@hotmail.com \\ Postal address: \\ PO Box 8067, Khartoum, \\ Sudan \\ Dates: \\ Received: 16 Mar. 2012 \\ Accepted: 14 Sept. 2012 \\ Published: 06 Dec. 2012 \\ How to cite this article: \\ EIGhali, A. \& Hassan, S.M., \\ 2012, 'Ticks infesting animals \\ in the Sudan and southern \\ Sudan: Past and current \\ status', Onderstepoort \\ Journal of Veterinary \\ Research 79(1), Art. \#431, \\ 6 pages. http://dx.doi. \\ org/10.4102/ojvr.v79i1.431
}

(C) 2012. The Authors. Licensee: AOSIS OpenJournals. This work is licensed under the Creative Commons Attribution License.
In this review, we collate information about ticks identified in different parts of the Sudan and South Sudan since 1956 in order to identify gaps in tick prevalence and create a map of tick distribution. This will avail basic data for further research on ticks and policies for the control of tick-borne diseases. In this review, we discuss the situation in the Republic of South Sudan as well as Sudan. For this purpose we have divided Sudan into four regions, namely northern Sudan (Northern and River Nile states), central Sudan (Khartoum, Gazera, White Nile, Blue Nile and Sennar states), western Sudan (North and South Kordofan and North, South and West Darfour states) and eastern Sudan (Red Sea, Kassala and Gadarif states).

\section{Introduction}

Ticks may have both direct and indirect adverse effects on their host animals. They feed on blood, leading to anaemia, and the injuries caused by their attachment damage hides and predispose animals to secondary bacterial infections that may lead to mastitis. These wounds may also be attractive to the myiasis-causing flies. Ticks can cause paralysis and probably transmit a greater variety of organisms that cause diseases than any other arthropod (Hoogstraal 1956). The economically most important tick-borne diseases are theileriosis, babesiosis, ehrlichiosis (heartwater) and anaplasmosis. The study of ticks that parasitise domestic animals is of considerable importance in that it assists in determining their host preference, their seasonality and geographic distribution, the diseases they may transmit and their control (King, Getting \& Newson 1988). On-host ticks may be affected by factors such as species, breed and immune status, whilst free-living ticks are affected by climate, geographic region and seasonality. During the late 1940s and early 1950s Hoogstraal $(1954,1956)$ collected ticks from more than 50 localities in Southern Sudan and 15 localities in Northern Sudan. He recorded 38 tick species in the southern Sudan provinces, seven in other provinces and 18 that were found in both Southern Sudan and other provinces.

In this review, we collate the findings on ticks identified in various regions of the Sudan and in South Sudan since Hoogstraal's survey (1956). The information should assist in filling some of the gaps in our knowledge about the ticks of the Sudan and South Sudan in order to compile a map illustrating tick distribution in both countries. The data could also provide a basis for further research on ticks and tick-borne diseases, which would be useful for developing control policies.

For the purposes of the review, we have included data from the Republic of South Sudan as well as from the Sudan, divided into northern Sudan (Northern and River Nile states), central Sudan (Khartoum, Gazera, White Nile, Blue Nile and Sennar states), western Sudan (North and South Kordofan and North, South and West Darfour states) and eastern Sudan (Red Sea, Kassala and Gadarif states). The localities are shown in Figure 1.

\section{Northern Sudan}

Hoogstraal (1956) identified Amblyomma exornatum, Hyalomma dromedarii, Hyalomma excavatum, Hyalomma impeltatum, Hyalomma impressum, Hyalomma marginatum, Hyalomma scupense (= Hyalomma detritum), Hyalomma rufipes, Hyalomma truncatum, Rhipicephalus evertsi evertsi, Rhipicephalus praetextatus and Rhipicephalus sanguineus in the northern provinces. Later, Salih et al. (2004) collected Hyalomma anatolicum from cattle in Atbara and Eddamer, and Hy. dromedarii from all localities sampled, as well as Rhipicephalus (Boophilus) decoloratus, Hy. impeltatum, Hy. truncatum, $H y$. rufipes, $R$. evertsi evertsi, $R$. praetextatus and ticks belonging to the $R$. sanguineus group from several localities. Ahmed, ElHussein and ElKhidir (2005) reported that in the River Nile State $74 \%$ of the ticks feeding on sheep were Hy. anatolicum, $15 \%$ R. praetextatus, $9 \%$ R. sanguineus group, $2 \%$ R. evertsi evertsi and $0.5 \% \mathrm{Hy}$. dromedarii. In the same area the species composition of ticks feeding on camels was Hy. dromedarii (89\%), Hy. impeltatum (7.7\%), Hy. anatolicum (3.3\%), Hy. truncatum (0.29\%), Hy. rufipes (0.25\%), R. praetextatus $(0.30 \%)$ and R. sanguineus group (0.09\%) 


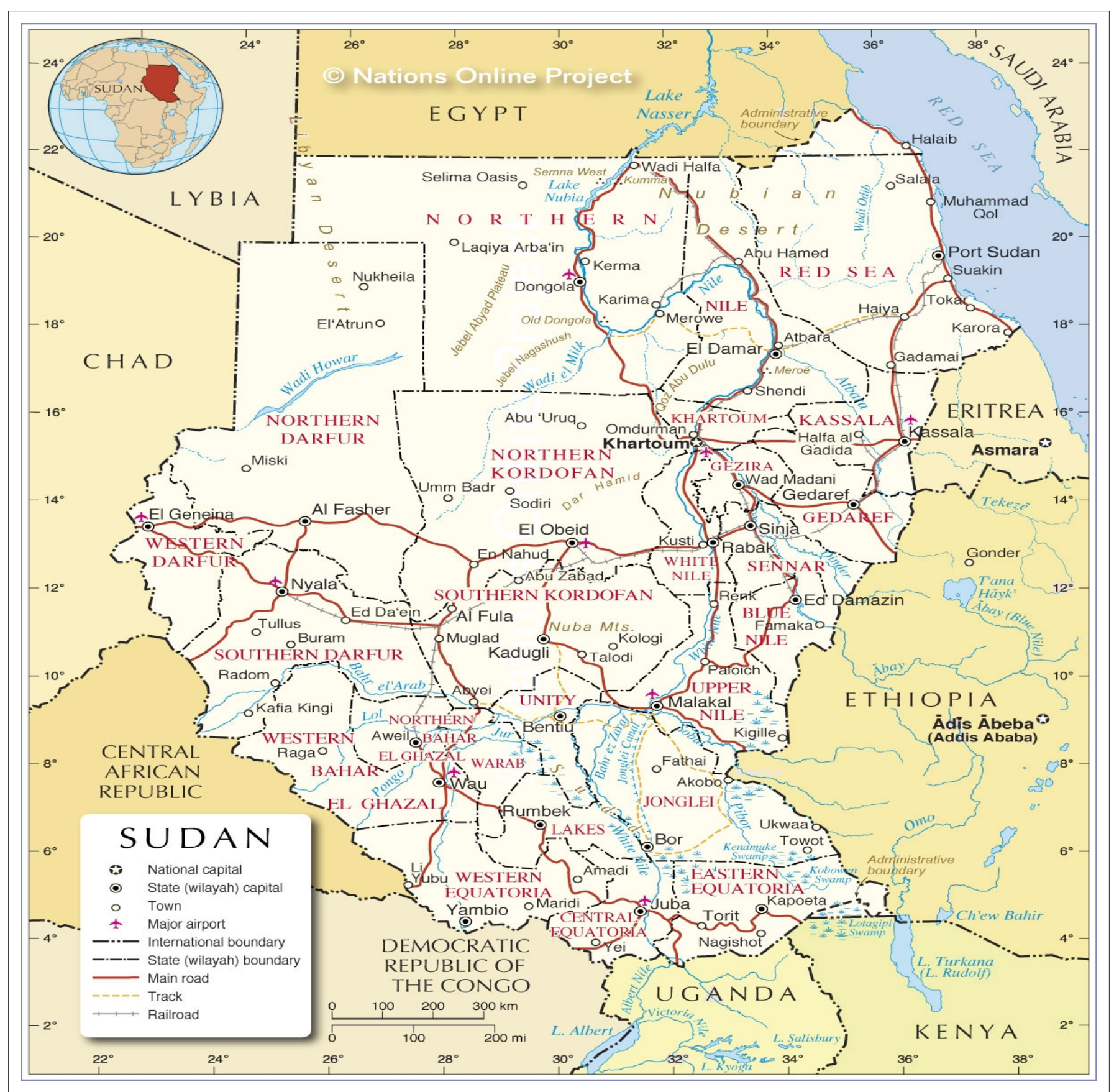

FIGURE 1: States of the Sudan and southern Sudan.

(ElGhali \& Hassan 2009). The predominant tick species feeding on horses in Atbara were Hy. anatolicum (= Hyalomma anatolicum anatolicum) (92\%) together with Hy. dromedarii, R. evertsi evertsi and R. sanguineus (Salim 2008).

\section{Central Sudan}

Hoogstraal (1956) recorded A. exornatum, Amblyomma lepidum, Amblyomma variegatum and $R$. (B.) decoloratus across central Sudan, except in Khartoum. Hy. scupense, Hy. dromedarii, Hy. excavatum, Hy. impeltatum, Hy. impressum, Hy. marginatum and Hy. rufipes were also recorded in central Sudan, except in the Blue Nile region (Hoogstraal 1956). Other species recorded in all states by Hoogstraal (1956) included R. evertsi evertsi, $R$. praetextatus and $R$. sanguineus. Just more than 25 years later the dominant tick species north and south of Wad Medani was Hy. anatolicum and a R. (Boophilus) species, respectively (FAO 1983). Tatchell (1983) stated that Hy. rufipes, R. evertsi evertsi and $R$. (B.) decoloratus were ubiquitous in their distribution along the Blue Nile, whilst the distribution of $\mathrm{Hy}$. anatolicum was restricted to north of Wad Medani. He further reported that A. lepidum was common only south of a line between Wad Medani and Khartoum, whilst Rhipicephalus (Boophilus) annulatus was restricted to the area south of Wad Medani.

Ticks of the Blue Nile and White Nile ecosystems were studied by Jongejan et al. (1987), who found 24 tick species infesting livestock and wildlife in these areas. Amongst these tick species Rhipicephalus (Boophilus) geigyi, Rhipicephalus bergeoni and Rhipicephalus camicasi were recorded for the first 
time in the Sudan. They also reported that $R$. (B.) annulatus had extended its distribution further north into the Blue Nile, Gezira and Khartoum regions. During 1979 to 1982, the immature stages of A. lepidum, Hy. anatolicum and $R$. evertsi evertsi were found feeding on cattle and sheep and immature $A$. variegatum specimens were collected from cattle (Latif 1985). Latif (1985) also found Hy. impeltatum nymphs on camels and sheep and Hy. dromedarii nymphs on camels for the first time.

In the Khartoum area, Gad Elrab (1986) reported Hy. anatolicum (= Hy. a. anatolicum), Hy. dromedarii, Hy. truncatum, R. evertsi evertsi, R. praetextatus and ticks of the $R$. sanguineus group on local sheep. Similarly, Osman (1999) collected Hy. anatolicum, $R$. evertsi evertsi and ticks of the $R$. sanguineus group from sheep on the Khartoum University Farm, north of Khartoum. Abdoon, Osman and EL Wasila (1992) collected 1344 ticks from horses, amongst which $97.4 \%$ were Hy. anatolicum and the rest Hy. dromedarii, Hy. rufipes and R. evertsi evertsi. In the southern parts of Khartoum, adjacent to Gazera State, exotic cattle were found to be infested with Hy. anatolicum, Hy. rufipes, R. (B.) decoloratus, R. evertsi evertsi and ticks of the R. sanguineus group (Mohamed, Aziz \& Kheir 1998). According to Mohammed (2002) A. lepidum was the predominant tick species in the Blue Nile State and infestation of host animals occurred throughout the year.

According to Lazarus (2002), who collected ticks from cattle in and around Wad Medani in central Sudan from May to July 2002, Hy. anatolicum was the most abundant species, followed by $R$. evertsi evertsi, Hy. rufipes, R. sanguineus, A. lepidum and R. (B.) decoloratus. All his collections of A. lepidum were male specimens. ElImam (2003) found that 11 tick species infested cattle in Kosti (central Sudan), amongst which A. variegatum, Hy. anatolicum and Hy. excavatum were reported for the first time in this area. Mohammed, Osman and ELrabaa (2004) recorded A. lepidum, Hy. anatolicum (70\% and $83 \%$, respectively) at Soba and Kuku and Hy. dromedarii, Hy. impeltatum, Hy. rufipes, R. evertsi evertsi and ticks of the $R$. sanguineus group on cattle in Khartoum. Salih et al. (2004) collected A. lepidum from cattle along the Blue Nile, from Wad Medani to Damazin and along the White Nile, from Eduaim to Rabak. They also found A. variegatum in Kosti. In addition, they collected Hy. anatolicum in Khartoum and in relatively high numbers in Um Benin (Blue Nile, south of Wad Medani), whilst Hy. dromedarii was present in all localities sampled except Kosti. Other ticks recorded by Salih et al. (2004) in other localities of central Sudan were R. (B.) decoloratus, Hy. impeltatum, Hy. rufipes, Hy. truncatum, R. evertsi evertsi, R. praetextatus and ticks of the R. sanguineus group. Export sheep (Hamari and Watish) brought to the Al Kadaro slaughterhouse (Khartoum State) from the White Nile, Blue Nile, Kordofan and Gadarif states were found to be infested with A. lepidum, Hy. anatolicum, Hy. dromedarii, Hy. impeltatum, Hy. rufipes, Hy. truncatum, R. (B.) decoloratus, R. camicasi, R. evertsi evertsi, Rhipicephalus guilhoni and Rhipicephalus muhsamae (Elfaki 2005).
Mohammed and Hassan (2007) studied the ticks that infested sheep in Sennar State and recorded A. lepidum, Hy. anatolicum (= Hy. a. anatolicum), Hy. truncatum, R. (B.) decoloratus, $R$. camicasi, R. evertsi evertsi, R. guilhoni and R. muhsamae. Salim (2008) found that the dominant tick species infesting horses in Kosti was Hy. anatolicum (= Hy. a. anatolicum) (92\%), whilst Hy. dromedarii, R. evertsi evertsi and R. sanguineus were also present. In the Butana area, Eltigani (2009) recorded A. lepidum, A. variegatum, Hy. anatolicum, Hy. dromedarii, Hy. impeltatum, Hy. rufipes, Hy. truncatum, R. (B.) decoloratus, $R$. evertsi evertsi and $R$. sanguineus on camels.

\section{Western Sudan}

Hoogstraal (1956) recorded A. exornatum, A. lepidum, A. variegatum and $R$. (B.) decoloratus in western Sudan and $R$. (B.) annulatus in Kordofan. He also reported the presence of Hy. dromedarii, Hy. excavatum, Hy. impeltatum, Hy. impressum, Hy. marginatum, Hy. rufipes, Hy. scupense, $R$ evertsi evertsi, $R$. praetextatus and $R$. sanguineus. Although Osman et al. (1982) later recorded various species of Amblyomma, Rhipicephalus (Boophilus) and Hyalomma in Kordofan, the dominant tick species was Hy. impeltatum. Osman (1997) also argued that the unusual distribution of A. lepidum and A. variegatum on sheep and goats in the Nuba Mountains required further study. In a subsequent study, cattle in Kadogli and Dilling in Kordofan State were found to be infested with A. lepidum, A. variegatum, Hy. rufipes, Hy. truncatum, R. (B.) annulatus, $R$. (B.) decoloratus, $R$. evertsi evertsi, $R$. praetextatus and ticks of the $R$. sanguineus group (Sowar 2002). In ElObeid, the predominant tick species on horses were $H y$. anatolicum (92\%), whilst Hy. dromedarii, R. evertsi evertsi and R. sanguineus were also present (Salim 2008). Salih et al. (2004) recorded A. lepidum on cattle at several localities in western Sudan, whilst A. variegatum was found in ElObeid and Nyala, and $H y$. dromedarii in all localities sampled.

In Darfour, Osman (1978a) found that Hy. rufipes, Hy. truncatum and $R$. sanguineus were the dominant species. He also recorded Hyalomma turanicum, R. (B.) annulatus, Rhipicephalus cuspidatus and Rhipicephalus sulcatus for the first time in Darfour and R. guilhoni and Rhipicephalus turanicus for the first time in the Sudan. Osman (1978b) recorded A. variegatum, Hy. dromedarii, Hy. rufipes, Hy. truncatum, $R$. (B.) decoloratus, R. evertsi evertsi, R. praetextatus, $R$. sulcatus and $R$. turanicus on sheep at Jebel Marra (Marra Mountain). Ticks belonging to the genera Amblyomma, Rhipicephalus (Boophilus), Hyalomma and Rhipicephalus were reported from cattle, camels and horses in and around Nyala town, with Hy. anatolicum present on dairy farms in Nyala (Gaafar 2008). Adam (2005) reported a single male Hy. anatolicum in Buram. Abdalla (2007) recorded 15 tick species belonging to four genera in South Darfour. These included A. lepidum, A. variegatum, Hy. anatolicum (only in Nyala town), Hy. dromedarii, Hy. impeltatum, Hy. impressum, Hy. rufipes, Hy. truncatum, R. (B.) annulatus, R. (B.) decoloratus, R. evertsi evertsi, $R$. guilhoni, R. muhsamae, R. praetextatus and R. sanguineus. With the exception of R. guilhoni, R. muhsamae and R. praetextatus, the same tick species as well as Hy. excavatum were found 
on dairy cattle in Nyala (Gaafar 2008). According to Ibrahim (2009), the dominant tick species infesting cattle and sheep in North Darfour was Hy. impeltatum, whilst A. lepidum, A. variegatum (accidental introduction possibly by migrating birds), Hy. dromedarii, Hy. rufipes, Hy. truncatum, R. (B.) decoloratus and $R$. evertsi evertsi were also present.

\section{Eastern Sudan}

In eastern Sudan, Hoogstraal (1956) recorded A. exornatum, A. lepidum, Hy. dromedarii, Hy. excavatum, Hy. impeltatum, Hy. impressum, Hy. marginatum, Hy. rufipes, Hy. scupense and R. (B.) decoloratus. He also reported Hy. truncatum in Kassala and $R$. evertsi evertsi, $R$. praetextatus and R. sanguineus in all provinces. Subsequently Karrar, Kaiser and Hoogstraal (1963) stated that $A$. lepidum numbers were high (15.5 ticks per host) in wooded savannah areas (River Atbara), the cultivated Gash Delta and in the Acacia seyal savannah of River Gash in Kassala. They also reported $R$. sanguineus on sheep, goats, cattle, camels and donkeys and that Hy. dromedarii was the most abundant tick species on camels. The latter species presented together with A. lepidum, Hy. excavatum, Hy. impeltatum, Hy. rufipes, Hy. truncatum, R. praetextatus and $R$. sanguineus. In the same area, Mohamed and Yagoub (1990) identified $R$. evertsi evertsi and R. sanguineus on cattle, sheep and equines (horses and donkeys), Hy. excavatum and Hy. rufipes on cattle and equines, whilst Hy. dromedarii, $H y$. marginatum and $R$. (B.) annulatus were collected only from cattle. Also in Kassala, Imam (1995) collected 4844 ticks from sheep, including the species A. lepidum, Hy. anatolicum, Hy. impeltatum, R. (B.) decoloratus, R. evertsi evertsi and ticks of the $R$. sanguineus group. Salih et al. (2004) collected A. lepidum from cattle in Gadarif and Port-Sudan, whilst a single Hy. anatolicum was collected from one animal in Port-Sudan and Hy. dromedarii from all localities except Kassala. In Gadarif, the predominant species on horses was Hy. anatolicum (92\%), with Hy. dromedarii, R. evertsi evertsi and R. sanguineus also being present (Salim 2008). ElGhali and Babikir (unpublished data) identified 291 ticks collected from 66 cattle in Elgalabat (near the Ethiopian boarder) during 2008, of which $60.6 \%$ were A. lepidum, followed by A. variegatum, Hy. anatolicum, Hy. rufipes, Hy. truncatum, R. (B.) decoloratus, R. evertsi evertsi, $R$. sanguineus and $R$. turanicus. In the Red Sea State, the predominant cattle ticks have been found to be Hy. anatolicum, Hy. dromedarii and Hy. impeltatum (Khalid 2009). Hy. anatolicum was also abundant in the Toker arera. Other species, including R. camicasi, R. (B.) decoloratus, R. evertsi evertsi and R. guilhoni have been collected in lesser numbers (Khalid 2009).

\section{Republic of South Sudan}

Hoogstraal (1956) recorded Amblyomma cohaerens, A. exornatum, Amblyomma latum, A. lepidum, Amblyomma marmoreum, Amblyomma nuttalli, Amblyomma pomposum, Amblyomma rhinocerotis, A. variegatum and Amblyomma tholloni in southern Sudan, together with $R$. (B.) annulatus and $R$. (B.) decoloratus. He recorded Dermacentor circumguttatus and Dermacentor rhinocerinus in Equatoria Province and Haemaphysalis aciculifer,
Haemaphysalis bequaerti, Haemaphysalis hoodi, Haemaphysalis houyi, Haemaphysalis leachii muhsami (= Haemaphysalis muhsamae), Haemaphysalis parmata and Hy. rufipes in all southern states. He also recorded Ixodes cavipalpus, Ixodes nairobiensis Ixodes rasus, Ixodes schillingsi, Ixodes simplex and Ixodes vespertilionis in Equatoria and Bahr El Ghazal Provinces. Furthermore, he recorded Margaropus reidi in Bahr El Ghazal Province and Rhipicephalus appendiculatus, Rhipicephalus arnoldi, Rhipicephalus bequaerti, Rhipicephalus compositus, R. cuspidatus, Rhipicephalus distinctus, R. evertsi evertsi, Rhipicephalus kochi, Rhipicephalus longicoxatus, Rhipicephalus longus, Rhipicephalus muehlensi, R. praetextatus, Rhipicephalus pravus, R. sanguineus, Rhipicephalus simpsoni, R. sulcatus, Rhipicephalus supertritus and Rhipicephalus tricuspis in the three provinces of South Sudan.

Rhipicephalus appendiculatus was first reported at Kajo Kaji and Yei in 1950 (Hoogstraal 1956). Later it was also reported in Chukudum, River, Nimuli, Yambio, Nagichot and Juba (Julla 2003). Morzaria et al. (1981) reported A. lepidum, A. variegatum, Hy. rufipes, R. appendiculatus, $R$. (B.) decoloratus, $R$. evertsi evertsi, $R$. praetextatus and $R$. pravus on cattle in the south. The dominant tick species in this region is A. variegatum (FAO 1983). Jongejan et al. (1987) reported that A. lepidum and $A$. variegatum had extended their distributions between latitude $5^{\circ} \mathrm{N}$ and $12^{\circ} \mathrm{N}$, whilst when compared to $R$. (B.) decoloratus, $R$. (B.) annulatus occupied the forest and wetter areas. Jongejan et al. (1987) also recorded R. (B.) geigyi from a single locality in South Sudan. By 1997, Rhipicephalus (Boophilus) microplus had not yet been recorded in the Sudan (Latif \& Hassan 1997). In the Pibor area in Jonglei State, Korok (2005) found that A. lepidum represented $56.6 \%$ of the tick population, $R$. sanguineus $20.5 \%$ and $R$. evertsi evertsi $16.2 \%$. Other tick species he recorded were A. variegatum, Hy. rufipes, R. (B.) annulatus, R. (B.) decoloratus and $R$. praetextatus. Marcellino (2008) recorded A. variegatum, Hy. rufipes, R. appendiculatus, R. (B.) decoloratus, R. evertsi evertsi, $R$. praetextatus and ticks of the $R$. sanguineus group on cattle in central Equatoria. He reported that $A$. variegatum was found in all the sampling localities. R. appendiculatus was abundant in the Juba area, whilst only a single male $R$. appendiculatus was identified in Mangalla and none in Terekeka.

\section{Discussion}

In the Sudan and South Sudan there are different geographic and climatic situations, ranging from the desert zone in the north (with an annual rainfall of less than $100 \mathrm{~mm}$ ) to wooded savannahs in the south (with annual rainfall of more than $1000 \mathrm{~mm}$ ). This extraordinary climatic and ecological diversity, coupled with a wide range of domestic and wildlife hosts, serve to accommodate the biological requirements of a variety of tick species. Hassan and Salih (unpublished data) report that factors such as animal movement, habitat change, drought, desertification and global climatic changes may force ticks to extend their distribution ranges beyond their known geographic regions. They report that $A$. variegatum has extended its range north of $12^{\circ} \mathrm{N}$, whilst $\mathrm{Hy}$. anatolicum 
has moved south of $14^{\circ} \mathrm{N}$ and $R$. (B.) annulatus was found in the semiarid zone. Abdalla and Hassan (2010) have recently reported on the distribution of A. variegatum, Hy. anatolicum and $R$. (Boophilus) species in various localities of Darfour State.

The distribution of some tick-borne diseases has been altered to some extent because of certain changes in the environment, the movement of animals to new pastures and the spread of certain tick species to new ecological zones. Heartwater, for instance, was originally restricted to the eastern parts of the country where a recognised vector, A. lepidum, was abundant (Abdel Rahim \& Shommein 1984; Karrar et al. 1963). According to Osman and Hassan (2003), A. lepidum is restricted to the eastern region, from Torit to Kapoeta in the south to Kassala in the north. Abdalla (2007) reported the presence of antibodies to Ehrlichia ruminantium (Heartwater causative agent) in Umdafug and in Reheid-arbirdi in southern Darfour State, and concluded that these results were due to changes in the geographic distribution of ticks and hence the disease. Furthermore, heartwater has recently become endemic in Kordofan and Darfour (Mohammed, unpublished data).

Tropical theileriosis (Theileria annulata infections) has been detected in new regions, to where the tick vector $\mathrm{Hy}$. anatolicum has extended its distribution range (Abdalla 2007; Gaafar 2008). Salih et al. (2004) collected Hy. anatolicum from cattle at Umbenein, in the southern regions of the Blue Nile State, proving that the species has extended its distribution southwards, which may lead to the emergence of tropical theileriosis in these areas. Adam (2005) detected T. annulata antibodies around Nyala and in Elradom, southern Darfour. In the same state, Abdalla (2007) reported T. annulata antibodies in cattle in Eid-elfirsan and concluded that this finding is linked to geographic changes in the distribution of the vector tick. The recovery of Hy. anatolicum in several localities in Darfour State (Abdalla \& Hassan 2010) confirm the observation.

Similarly, East Coast fever (Theileria parva infection) coincides with the distribution of $R$. appendiculatus in the southern part of South Sudan. The first outbreak of East Coast fever was reported in 1950 in the Kajo Kaji and Yei districts on the western bank of the Nile and extended up to Juba (Julla 1985, 1994). The disease was found to be more prevalent in areas that were used for grazing during the dry season, namely Apuk toich, River Lol and the Aweil district (Zessin \& Baumann 1982). In the south, scattered tick collections proved that $R$. appendiculatus has moved northwards up to Bore (Julla 2003) and may lead to the occurrence East Coast fever in the southern regions of the north.

\section{Conclusion}

In conclusion, numerous tick species are distributed throughout the Sudan and South Sudan and these include the economically most important vectors of disease. Several of the vector tick species have expanded their distribution beyond their previously recognised geographical zones, which may lead to the expansion of tick-borne diseases to new areas where outbreaks of disease are expected to be drastic. Furthermore, ticks and tick-borne diseases in the Sudan represent one of the most important obstacles to livestock production. Hence it seems that without control of ticks and tick-borne diseases, it would be almost impossible to increase livestock production with foreign-breed animals, selection from indigenous breeds or through cross-breeding (Osman 1976).

\section{Acknowledgements Competing interests}

The authors declare that they have no financial or personal relationship(s) that may have inappropriately influenced them in writing this paper.

\section{Authors' contributions}

A.E. (Veterinary Research Institute) suggested the concept of the review, collected most of the used articles and other references, designed the review, wrote the first draft of the review and submitted the review. S.M. H. (University of Khartoum) added some references, improved the written paper and revised all information, particularly the recent tick names.

\section{References}

Abdalla, M.M., 2007, 'Studies on ticks and tick-borne diseases of cattle in South Darfour State, Sudan', MVSc thesis, Department of Parasitology, University of Khartoum.

Abdalla, M.M. \& Hassan, S.M., 2010, 'Current status of distribution of ticks (Acari: Ixodidae) infesting cattle in South Darfour State, Sudan', University of Khartoum Journal of Veterinary Science and Animal Production 1(2), 76-97.

Abdel Rahim, A.I \& Shommein, A.M., 1984, 'Heartwater in the Sudan with emphasis on Eastern Region', paper presented at the 11th Veterinary Conference of Animal Wealth, Kassala, Eastern Sudan, 10-14th April, pp. 129-139.

Abdoon, A.M.O., Osman, O.M. \& EL Wasila, M., 1992, 'The epidemiology of equine babesiosis in Khartoum District, Sudan. 1 - Tick prevalence and their parasite rate', Bulletin of Animal Health and Production in Africa 40, 11-14.

Adam, M.E., 2005, 'Prevalence of blood parasites in domestic animals in South Darfour State of Sudan', MVSc thesis, Department of Parasitology, University of Khartoum.

Ahmed, B.M., ElHussein, A.M. \& ElKhidir, A.O., 2005, 'Some observations on ticks (Acari: Ixodidae) infesting sheep in River Nile State of Northern Sudan', Onderstepoort Journal of Veterinary Research 72, 239-243.

Elfaki, B.H., 2005, 'Studies on ticks and tick-borne diseases of export sheep at Alkadaro slaughter house', MVSc. thesis, Department of Parasitology, University of Khartoum.

EIGhali, A. \& Hassan S.M., 2009, 'Ticks (Acari: Ixodidae) infesting camels (Camelus dromedarius) in Northern Sudan', Onderstepoort Journal of Veterinary Research 76, 177-185.

EIGhali, A. \& Babikir, A., n.d., 'Identification of ticks collected from cattle in Elgalabat Eastern Sudan', unpublished data.

Ellmam, A.H., 2003, 'Ecological studies of ticks (Acari: Ixodidae) infesting cattle in Kosti Province, Sudan', Sudan Journal of Veterinary Science and Animal Husbandry 42 (1 \& 2), 62-71.

Eltigani, M. A., 2009, 'Prevalence of ticks (Acari: Ixodidae) infesting camels in Butana area, Central Sudan', MSc thesis, Animal Resources Research Council, Sudan Academy of Sciences.

FAO. See Food and Agriculture Organization.

Food and Agriculture Organization/Sudan tick and tick-borne disease control project terminal report, 1983, 'Project findings and recommendations', pp. 5-8.

Gaafar, B.B.M., 2008, 'Epidemiology of tropical theileriosis in Nyala dairy farms in Southern Darfour State, Sudan', MVSc. thesis, Department of Parasitology, University of Khartoum.

Gad Elrab, N.E., 1986, 'A survey of sheep piroplasmosis in Khartoum Province, central Sudan', MSc thesis, Department of Parasitology, University of Khartoum.

Hassan, S.M. \& Salih, D.A, n.d., 'Ecological factors affecting distribution of ticks in the Sudan', unpublished data. 
Hoogstraal, H., 1954, 'A preliminary annotated list of ticks (Ixodoidea) of the Anglo-Egyptian Sudan', Journal of Parasitology 40(3), 304-310. http://dx. doi. org/10.2307/3273742, PMid:13184376

Hoogstraal, H., 1956, African Ixodoidea. 1. Ticks of the Sudan with special reference to Equatoria province and with preliminary review of genera Rhipicephalus, Margaropus and Hyalomma, US Navy, Washington D.C.

Ibrahim, S.A.H., 2009, 'Tick and tick-borne diseases of cattle and sheep in North Darfour State, Sudan', MTAH thesis, Department of Parasitology, University of Khartoum.

Imam, H.B., 1995, 'Epidemiological studies of sheep theileriosis in Kassala area', MVSc thesis, Parasitology department, University of Khartoum.

Jongejan, F., Zivkovic, D., Pegram, R.G., Tatchell, R.J., Fison T., Latif, A.A. et al., 1987 'Ticks (Acari: Ixodidae) of the Blue and White Nile Ecosystems in the Sudan with particular reference to the Rhipicephalus sanguineus group', Experimental and Applied Acarology 3, 331-346. http://dx.doi.org/10.1007/BF01193169

Julla, I.I., 1985, 'Theileriosis in Southern Sudan', in Proceedings of a workshop held at ILRAD, Nairobi, Kenya, October 01-05, 1984, pp. 27-30.

Julla, I.I., 1994, 'Studies on the epidemiology of theileriosis in Equatoria Region of the Sudan with emphasis on East Coast Fever', PhD thesis, Department of Parasitology, University of Khartoum.

Julla, I.I., 2003, 'East Coast fever (T. parva infection of cattle) in southern Sudan: An overview', Sudan Journal of Veterinary Science and Animal Husbandry $42(1 \& 2)$, 141-146.

Karrar, G., Kaiser, M.N. \& Hoogstraal, H., 1963, 'Ecology and host-relationship of ticks (Ixodoidea) infesting domestic animals in Kassala Province, Sudan with special reference to A. lepidum Donitz', Bulletin of Entomological Research 54(3), 509522. http://dx.doi.org/10.1017/S0007485300048987

Khalid, S.M.K., 2009, 'Prevalence of ticks and tick-borne diseases of cattle in the Red Sea State, Sudan', MVSc thesis, Department of Parasitology, University of Khartoum

King, D., Getting, G. \& Newson, R.M., 1988, 'A climate-based model for the development of the ixodid tick, Rhipicephalus appendiculatus in East Coast feve zones', Veterinary Parasitology 29, 441-451. http://dx.doi.org/10.1016/03044017(88)90006-4

Korok, J.M., 2005, ' Ecological and epidemiological studies on ticks (Acari: Ixodidae) in Pibor area, Jonglei State', MVSc thesis, Department of Parasitology, University of Khartoum.

Latif, A.A., 1985, 'Tick (Acari: Ixodidae) immatures feeding on cattle, camels and sheep in the Sudan, with notes on behaviour of Hyalomma anatolicum anatolicum larvae fed on different hosts', Insect Science Application 6(1), 59-61.

Latif, A.A. \& Hassan, S.M., 1997, 'Geographic distribution of ticks in the Sudan using computer models', project report, International Workshop held at ICIPE, Nairobi, Kenya, 09-19th September.

Lazarus, A.G., 2002, 'Epidemiological studies on ticks and tick-borne diseases of bovine in and around Wad-Medani town, central Sudan', MVSc thesis, Department of Parasitology, University of Khartoum.

Marcellino, W.L., 2008, 'Prevalence and economic impact of East Coast fever in Centra Equatoria State, Southern Sudan', MSc thesis, Animal Resources Research Council, Sudan Academy of Sciences.
Mohamed, A.A. \& Yagoub, I.A., 1990, 'Outbreaks of babesiosis in domestic livestock in eastern region of the Sudan', Tropical Animal Health and Production 22(2), 123-125. http://dx.doi.org/10.1007/BF02239838, PMid:2371750

Mohamed, Y.O., Aziz, A.A. \& Kheir, S.M., 1998, 'Ticks and tick-borne diseases survey in Khartoum State', Sudan Journal of Veterinary Science and Animal Husbandry $37(2), 282-289$

Mohammed, A.S., 2002, 'Studies on some biological aspects on the tick Amblyomma lepidum (Donitz 1909) under natural field conditions in the Blue Nile State, Sudan', $\mathrm{PhD}$ thesis, Department of Preventive Medicine, University of Khartoum.

Mohammed, A.S., Osman, O.M. \& ELrabaa, F.M., 2004, 'The occurrence of Ixodid tick species of cattle in two localities of Khartoum District', Sudan Journal of Veterinary Science and Animal Husbandry 43(1 \& 2), 118-122.

Mohammed, M.S. \& Hassan, S.M., 2007, 'Distribution and population dynamics of ticks (Acari: Ixodidae) infesting sheep in Sennar State, Sudan', Onderstepoort Journal of Veterinary Research 74, 301-306. PMid:18453239

Mohammed, S., n.d., 'Heartwater in the Sudan', unpublished data.

Morzaria, S.P., Tatchell, R.J., Minor, R., Pedersen, V., Julla, I.I., Rahim, A. et al., 1981 'Preliminary studies of epidemiology of theileriosis in Eastern Equatoria Province of Sudan', in A.D. Irvin, M.P. Cunningham \& A.S. Young (eds.), Advances in the control of theileriosis, pp. 83-85, Marinus Nijhoff, The Hague.

Osman, A.M., 1976, 'A review on tick-borne diseases in Sudan and their control', Bulletin of International Epizootics 86, 80-87.

Osman, A.M., 1997, 'Ticks infesting sheep and goats in the Sudan', Parasitologia 39, 139-142.

Osman, A.M. \& Hassan, S., 2003, 'The ecology and distribution of the East Africa tick A. lepidum', Sudan Journal of Veterinary Science and Animal Husbandry 42(1\&2) 45-53.

Osman, I.A., 1999, 'Some studies on malignant ovine theileriosis in Northern Sudan' MVSc thesis, Department of Parasitology, University of Khartoum.

Osman, O.M., 1978a, 'Preliminary notes on the distribution of ticks (Acarina: Ixodidae) in Darfour Province, Sudan', Bulletin of Animal Health and Production in Africa 26, 329-333. PMid:756756

Osman, O.M., 1978b, 'A note on ticks in Jebel Marra', Sudan Journal of Veterinary Science and Animal Husbandry 19(2), 124-126.

Osman, O.M., El Hussein, A.M., Ahmed, N. \& Abdulla, H.S., 1982, 'Ecological studies on ticks (Acari: Ixodidae) of Kordofan region, Sudan', Bulletin of Animal Health and Production 30, 45-53.

Salih, D.A., Hassan, S.M., El Hussein, A.M. \& Jongejan, F., 2004, 'Preliminary survey of ticks (Acari: Ixodidae) on cattle in Northern Sudan', Onderstepoort Journal of Veterinary Research 71, 319-326. PMid:15732459

Salim, B.O.M., 2008, 'Molecular, serological and parasitological detection of piroplasmosis of horses in the Sudan', MVSc thesis, Department of Parasitology, piroplasmosis of horses in
University of Khartoum.

Sowar, A.E., 2002, 'Epidemiology and ecology of ticks and some tick-borne diseases in (Kadogli and Dilling) Southern Kordofan State, Sudan', MVSc thesis, Department of Preventive Medicine, University of Khartoum.

Tatchell, R.J., 1983, 'Tick and tick-borne diseases control. The Sudan. Tick Ecology and Tick control', technical report, AG: GCP/SUD 024/DEN, Food and Agriculture Organization of United Nations, Rome.

Zessin, K.H. \& Baumann, M.P., 1982, 'Report on the livestock disease survey, Bahr El Ghazal Province', Technical Cooperation Germany/Sudan, GTZ, Berlin. 